\title{
Occurrence of High Acetic Acid-Producing Bacteria in Ivorian Cocoa Fermentation and Analysis of Their Response to Fermentative Stress
}

\author{
Souleymane Soumahoro, Honoré Gnenéquidou Ouattara*, Bernadette Gblossi Goualié, \\ Gisèle Koua, Ginette Doue, Sébastien Lamine Niamke
}

Laboratory of Biotechnology, UFR Biosciences, University Félix Houphouët-Boigny, Abidjan, Côte d'Ivoire

Email address:

kidou12@yahoo.fr (H. G. Ouattara)

\section{To cite this article:}

Souleymane Soumahoro, Honoré Gnenéquidou Ouattara, Bernadette Gblossi Goualié, Gisèle Koua, Ginette Doue, Sébastien Lamine Niamke. Occurrence of High Acetic Acid-Producing Bacteria in Ivorian Cocoa Fermentation and Analysis of Their Response to Fermentative Stress. American Journal of BioScience. Vol. 3, No. 3, 2015, pp. 70-79. doi: 10.11648/j.ajbio.20150303.12

\begin{abstract}
Acetic acid produced during cocoa fermentation impact strongly the quality of fermented and dried cocoa beans and chocolate. The objective of this study was to analyze acid production in Acetic acid bacteria (AAB) and their response to fermentative conditions. AAB strains were isolated from cocoa fermentation and screened for acid production on both solid and liquid media. From 444 isolates, 15 strains yielded 2 to $38.1 \mathrm{~g} / \mathrm{L}$ of acid in liquid medium. The best acid producers were identified by biochemical typing as Acetobactersp, Acetobacteraceti, A. peroxydans, A. pasteurianus and Gluconobacteroxydans. Most AAB strains showed strong tolerance to alcohol with round $45 \%$ of survival growth rate (SGR) under $12 \%$ ethanol. AAB strains growing well at $2 \%$ acetic acid (SGRround $47 \%$ ), failed to grow at $3 \%$ of this acid. Lactic acid has the most hindering effect on AAB growth, provoking a drop of SGR from $100 \%$ to less than $25 \%$ at only $1 \%$ of lactic acid. Maximum growth of acidifying AAB strains occurred at $35^{\circ} \mathrm{C}$. This study evidences the diversity of technological performances of $\mathrm{AAB}$ involved in Ivorian cocoa fermentation and allows targeting the most valuable strains as starters.
\end{abstract}

Keywords: AAB Growth, Acetic Acid Production, Acetobacter, Cocoa Fermentation, Stress Tolerance

\section{Introduction}

Fermentation is an indispensable step in the transformation process of cocoa into chocolate and has a great impact on the flavor, color and aroma of cocoa products $[1,2,3]$. During cocoa fermentation, complex biochemical reactions triggered by the microbial flora occur and allow the production of cocoa and chocolate with desirable organoleptic characteristic $[4,2,5,6]$.

Although, the whole microflora responsible for cocoa fermentation including essentially yeasts, lactic acid bacteria, acetic acid bacteria and Bacillus is relatively well-known, their different physiological roles remain complex and not sufficiently elucidated [7, 8, 9, 10, 11].

However, yeasts and acetic acid bacteria present the most well-known roles. Yeast present at the onset of the fermentative process, oxidize sugars contained in the pulp into alcohol and breakdown the pulp by pectinolytic enzymes production $[12,2,13,3]$. Acetic acid bacteria further oxidize alcohol produced by yeasts, into acetic acid which diffuses deep into cotyledons, acidifying the beans and activating inner hydrolytic enzymes [1, 12, 9, 14]. Furthermore, enzymes activated under acidic conditions notably aspartic endoprotease and serine carboxypeptidase both being $\mathrm{pH}$ dependent, generate the specific precursors of chocolate aroma $[1,15]$. Hence, the lowering of the $\mathrm{pH}$ into cocoa bean is of great importance in the fermentative process for the generation of quality of products.At date, it is well established that acetic acid bacteria play a key role in the formation of the precursors of chocolate flavor $[16,2,17]$. Due to its acidifying properties and the easy diffusion of acetic acid into beans, Acetic acid bacteria are assumed to be one of the most valuable microbial flora in cocoa fermentation $[2,14]$.

On the other hand, cocoa fermentation is still a traditional process difficult to control which gives variable and non- 
reproducible quality of fermented and dried beans leading very often to a low crop value for farmers. As a solution to overcome this problem, the utilization of microbial starter culture stands the most promising approach, since it should permit, to efficiently control and standardize the process of cocoa fermentation $[7,18,5]$.

As it is well known that microbial strains with acidification capacity are desirable for the production of cocoa bean and chocolate of quality, the acidification capacity is therefore an interesting technological property to be considered for microbial starter screening. However, no further investigation has been undertaken on this property in these bacterial strains involved in cocoa fermentation.

This paper report the biochemical characterization of $\mathrm{AAB}$ strains presenting high acidification capacity and evaluation of their growth ability under fermentative stress conditions.

\section{Material and Methods}

\subsection{Fermentation Conditions and Isolation of Acetic Acid Bacteria}

Cocoa pods were collected from three areas of Côte d'Ivoire notably Agboville (geographic coordinates 5 59' North $4^{\circ} 28^{\prime}$ West), Divo (5 $55^{\prime}$ North $5^{\circ} 37^{\prime}$ West) and Aboisso $\left(5^{\circ} 28^{\prime} 06^{\prime}\right.$ North $3^{\circ} 12^{\prime} 25^{\prime}$ 'West). Fermentation was processed for six days as described by Yao et al. [19]. Samples were withdrawn at $12 \mathrm{~h}$ intervals for acetic acid bacteria isolation and numeration. After appropriate dilution in sterile saline solution, $0.1 \mathrm{~mL}$ of the fresh fermenting samples were plated on potato medium containing $0.5 \%$ D-glucose, $1 \%$ yeasts extract, $1 \%$ peptone, $2 \%$ glycerol, $1.5 \%$ potato and $4 \%$ ethanol (v/v), supplemented with $0.0016 \%$ bromocresol green to monitor $\mathrm{pH}$ variation and nystatin $(50 \mu \mathrm{g} / \mathrm{ml})$ to inhibit fungal growth[20]. After $48 \mathrm{~h}$ incubation at $30^{\circ} \mathrm{C}$, Acetic acid bacteria were identified based on following tests: Gram staining, catalase, oxidase and respiratory metabolism. Colony count enumeration was expressed as CFU per gram cocoa pulp-bean mass. The strains isolated were kept at $-80{ }^{\circ} \mathrm{C}$ in Luria Bertani medium supplemented with glycerol $20 \%$ in Eppendorf tubes, for further studies.

\subsection{Quality Control Methods}

\subsubsection{Screening of Acidifying AAB Strains}

Screening of acidifying AAB isolates was carried out in both solid and liquid media.

In solid medium the strains were screened for their acidifying property based on clear halo diameter using Hestrin-Schramm (HS) medium composed of $0.05 \%$ glucose, $0.3 \%$ peptone, $0.5 \%$ Yeast extract, $1.5 \% \mathrm{CaCO}_{3}$, $1.2 \%$ agar, and $4 \%$ ethanol as describedinprevious study [21]. The medium was spot inoculated with pure $24 \mathrm{~h}$ preculture of bacterial strain and incubated at $30{ }^{\circ} \mathrm{C}$ for 10 days. Acidifying capability of strains was assessed by acid forming colony characterized by a clear halo with a diameter related to the amount of acid produced.

In liquid medium, the production of acetic acid was evaluated according to the method described by Nanda et al. [22].Acid production medium was prepared by adding 1.0 $\mathrm{mL}$ of a 24 hours pre-culture $\left(\mathrm{OD}_{600}=0.5\right)$ of acetic acid bacteria strains into $150 \mathrm{~mL}$ of calcium free HestrinSchramm (HS) broth contained in $250 \mathrm{~mL}$ Erlenmeyer flask. To this HS medium, $0.01 \% \mathrm{MgSO}_{4}$ and $0.27 \% \mathrm{NaHPO}_{4}$ were added to promote acid production. The medium was incubated for 10 days under aerobic atmosphere at $30{ }^{\circ} \mathrm{C}$ with stirring at $130 \mathrm{rpm}$. During incubation a $10 \mathrm{~mL}$ daily sample of liquid medium were taken and analyzed for determination of growth rate, $\mathrm{pH}$ of medium and quantification of acid produced.

The growth rate was directly determinate by measurement of culture medium absorbance at $600 \mathrm{~nm}$. The $\mathrm{pH}$ was measured in cell free supernatant after centrifugation of the culture medium at $4500 \mathrm{rpm}$. Acid yield was quantified in cell free supernatants by titration with $\mathrm{NaOH}(0.1 \mathrm{~N})$ and phenolphthalein as a color indicator. Acid production was expressed as grams of acetic acid per $100 \mathrm{~mL}$ using the following relation:

$$
\text { Acidity }(\%)=\left[\mathrm{V}\left({ }_{\mathrm{NaOH}}\right) \times 0.1 \times 0.06 / \mathrm{V}_{\text {(supernatant used) }}\right] \times 100
$$

\subsubsection{Characterization of High Acetic Acid Producing Strains}

AAB displaying high acid production were subjected to biochemical characterization for further identification of strains at species level. A scheme of biochemical tests allowing a simple and rapid identification of strains were performed as described by Buchanan and Gibbon, [23]. The first step of biochemical characterization concerned the oxidation of both acetic and lactic acids which allow to distinguish strains belonging to Acetobacter genus from those belonging to Gluconobacter genus. The test of oxidation was performed in HS broth medium containing $0.05 \%$ glucose and $1 \%$ acetic acid or lactic acid as carbon source. Addition of acetic acid or lactic acid to the HS broth provokes the change of the green medium color into yellow [19]. One fresh colony of acetic acid bacteria was inoculated in $3 \mathrm{~mL}$ of HS broth and then incubated at $30^{\circ} \mathrm{C}$ for 48 hours in aerobic atmosphere. Oxidation of acetic acid or lactic acid was assessed by the change of medium color back to green, due to $\mathrm{pH}$ rise.

Next, a panel of biochemical test performed, included sugars metabolism particularly galactose and mannose, acid production from glucose, nitrate reduction and ketogenesis from glycerol and mannitol.

The test of carbohydrate catabolism was carried out in basal liquid medium containing peptone (3\%); $\mathrm{K}_{2} \mathrm{HPO}_{4}$ $(0.05 \%) ; \quad \mathrm{KH}_{2} \mathrm{PO}_{4}(0.05 \quad \%) ; \mathrm{MgSO}_{4} \quad(0.01 \quad \%)$; $\left(\mathrm{NH}_{4}\right)_{2} \mathrm{SO}_{4}(0.14 \%)$ with $1 \%$ of tested sugar as sole source of carbon. Acid production from glucose was tested in HS medium supplemented with $0.0016 \%$ of bromocresol green and $1 \%$ of the sugar was used. The test of nitrate reduction was performed in liquid medium containing $0.3 \%$ yeast extract, $0.5 \%$ peptone and $0.1 \%$ potassium nitrate. After 48 hours incubation at $30{ }^{\circ} \mathrm{C}$, nitrate reduction into nitrite was revealed by addition of Griess reagent (Sigma-Aldrich, 
Abidjan). Ketogenesis from glycerol and mannitol was detected by the methods outlined by Carr,[24].

\subsubsection{Analysis of Strains Resistance to Fermentative Stress}

\section{(i). Resistance to Alcoholic and Acid Stress}

Evaluation of resistance to ethanol, lactic acid, acetic acid and citric acid stress was carried out on YEP agar medium as described by Pereira et al. [25] and modified by Samagaci et al. [26].To prepare the stress medium, the YEP medium was cooled after autoclaving and maintained in liquid state at $45^{\circ} \mathrm{C}$ in water bath and then appropriate quantity of alcohol or acid was aseptically added to the medium to obtain the fixed concentration. The concentration of ethanol, lactic acid, acetic acid and citric acid were added with different final concentrations $(\mathrm{v} / \mathrm{v})$ ranging from 0.1 to $20 \%$ depending on the compound. The negative control was prepared in the same conditions except that it did not contain the corresponding compound studied. A standard initial load of bacterial inoculum was prepared by suspending a 16-24 h old colonies in $5 \mathrm{~mL}$ of sterile saline buffer to obtained an $\mathrm{OD}_{600}$ $=0.1$. Then this suspension was $10^{6}$-fold diluted and $100 \mu \mathrm{L}$ of this diluted bacterial suspension was used as inoculum. The plate were then seeded with approximately the same bacterial load and incubated at $30{ }^{\circ} \mathrm{C}$ for 3 days in aerobic conditions. The capacity of strains to resist to alcoholic and acid stress is assessed by the growth of colony and the survival rate was determined after colonies count according to the following relation.

\section{Survival rate $=(\Sigma \mathrm{AAB}$ colony with alcohol or acid $/$ $\Sigma$ AABcolony in negative control) $\times 100$ )}

\section{(ii). Effects of Temperature and pH on AAB Growth}

Effects of temperature and $\mathrm{pH}$ on the growth of $\mathrm{AAB}$ strains were analyzed in liquid medium as described by Pereira et al. [25] with slight modification. Bacterial cells were grown at $30{ }^{\circ} \mathrm{C}$ in YEPG medium until $\mathrm{OD}_{600}=0.1$, then $500 \mu \mathrm{L}$ of this pre-culture were added in $10 \mathrm{~mL}$ of YEPG broth and then the cultures were incubated at different temperatures ranging from 30 to $50{ }^{\circ} \mathrm{C}$.

To evaluate the effect of $\mathrm{pH}$ on $\mathrm{AAB}$ growth, the YEPG broth medium is adjusted to different $\mathrm{pH}(2 ; 3 ; 5 ; 7$ and 8$)$. The absorbance $\left(\mathrm{OD}_{600}\right)$ was measured at $6 \mathrm{~h}$ intervals to monitor the microbial growth during incubation.

\section{(iii). Influence of Sugar Concentration on AAB Growth}

The influence of sugar concentration on the growth of AAB was performed as described by Samagaci et al. [26] with modification. To prepare the culture medium, YEP broth was supplemented with glucose at different concentrations $(5 \%, 10 \%, 15 \%, 20 \%, 25 \%$ and $30 \%)$. After sterilization, $9 \mathrm{~mL}$ of the medium is inoculated with $1 \mathrm{~mL}$ of AAB cells pre-culture $\left(\mathrm{OD}_{600}=0.5\right)$ and then incubated at $30{ }^{\circ} \mathrm{C}$ for 7 days. The absorbance was measured at $600 \mathrm{~nm}$ against the sterile YEP medium to determine the turbidity, using a spectrophotometer PIOWAY Medical Lab - UV 752.

\section{Results and Discussion}

\subsection{Screening of Producing AAB Strains}

From fermenting cocoa beans in three regions, a total of 444 AAB strains were isolated. This strains showed naturally acidification capacity but with different levels of acid production. Among these isolates, 97 strains showed the most important acidification capacity with clear halo diameter ranging from 1.7 to $3.1 \mathrm{~cm}$. Moreover, 226 strains produced middle acidity with halo diameter in the range $1.1-1.7 \mathrm{~cm}$ and 85 isolates showed weak acidification capacity (Figure 1).

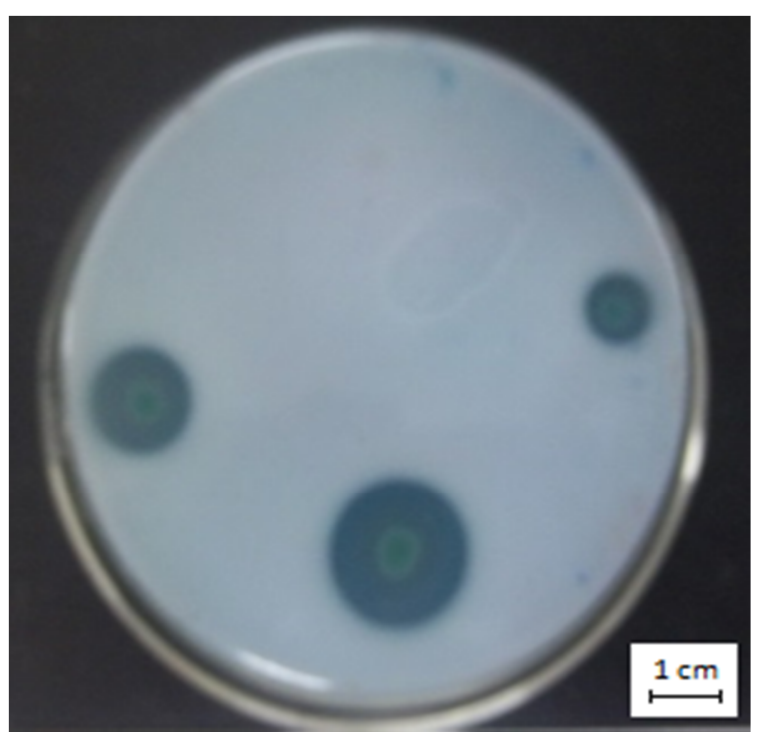

Figure 1. Screening of $A A B$ with different levels of acid production.

+ Strains were cultured on Hestrin-Schramm (HS) medium composed of $0.05 \%$ glucose, $0.3 \%$ peptone, $0.5 \%$ yeast extract, $1.5 \% \mathrm{CaCO}_{3}, 1.2 \%$ agar, and $4 \%$ ethanol and incubated at $30^{\circ} \mathrm{C}$ for 10 days[21]. Acidifying capability of strains is characterized by a clear halo with a diameter related to the amount of acid produced.

The most acidifying strains (97) screened on solid medium, were further tested to evaluate the yield of acetic acid in liquid medium. Among these isolates, only $15 \mathrm{AAB}$ strains yielded 2 to $38 \mathrm{~g} / \mathrm{L}$ of acid (Table 1). The highest acid production $(38.1 \mathrm{~g} / \mathrm{L})$ was achieved with the strain $121 \mathrm{D}$ from Divo cocoa fermenting bean. Four (04) strains including $5 \mathrm{D} ; 56 \mathrm{AB} ; 139 \mathrm{D}$ and $123 \mathrm{D}$ also showed a good ability to produce acetic acid in liquid medium with 12.9 , 13.4, 17.2 and $13.9 \mathrm{~g} / \mathrm{L}$ of acid quantity respectively (Table 1). Acid production in these strains was characterized by a rapid decrease of the $\mathrm{pH}$ in the culture medium within 5 days dropping generally from 7.06 to 4.20 (data not shown).

The results show that although all the 444 strains analyzed have an acidification capacity, there is a difference in term of amount of acid produced. Hence the strains 121D as the most acidifying strain, yielded $38.1 \mathrm{~g} / \mathrm{L}$ of acetic acid from ethanol. This production is particularly higher than that from $\mathrm{AAB}$ in Mexican cocoa fermentation reported by RomeroCortes et al. [27]which was $25 \mathrm{~g} / \mathrm{L}$. However, Sharafi et al. [28] isolated $\mathrm{AAB}$ (Acetobacterpasteurianus) from fruit with 
capacity to produce up to $100 \mathrm{~g} / \mathrm{L}$ of acetic acid while Konaté et al. [29]reported $\mathrm{AAB}$ (Acetobacterpasteurianus) as the best acid producer from traditional palm wine producing $30 \mathrm{~g} / \mathrm{L}$ of acetic acid. At date, the strain 121D isolated in this study, present the higher acetic acid production from cocoa fermentation.

The time course of acid production in these strains shows an irregular increase of acid amount in the liquid medium. A fair acid production characteristic of lag phase was observed in the four first days followed by a sharp rise of acid production in the period stretching from the fifth and the height day and become stable the remaining time at the maximum acid production (Figure 2). In solid medium, acid production was also assessed by an increase of halo diameter although a poor correlation was observed between the acid halo diameter in solid medium and the quantity of acid produced in liquid medium $\left(\mathrm{R}^{2}=21.05\right)$.
Table 1. Acid production from different isolates on solid and in liquid medium.

\begin{tabular}{lll}
\hline Isolates & $\begin{array}{l}\text { Clear halo } \\
\text { diameter (en cm) }\end{array}$ & $\begin{array}{l}\text { Amount of acid } \\
\text { produced (g/L) }\end{array}$ \\
\hline 168 AG (A.pasteurianius) & $3.10 \pm 0.1$ & $2.4 \pm 0.0$ \\
154 AG (A.aceti) & $3.05 \pm 0.1$ & $2.1 \pm 0.0$ \\
153 AG (A.pasteurianius) & $2.9 \pm 0.1$ & $3.2 \pm 0.2$ \\
139 AG (A.aceti) & $2.85 \pm 0.06$ & $3.9 \pm 0.0$ \\
140 AG (A.pasteurianius) & $2.55 \pm 0.1$ & $3.5 \pm 0.2$ \\
52 AB (A.aceti) & $2.10 \pm 0$ & $5.7 \pm 0.2$ \\
56 AB (A.peroxydans) & $2.10 \pm 0.1$ & $13.4 \pm 0.2$ \\
139 D (A.aceti) & $2.05 \pm 0.57$ & $17.2 \pm 0.2$ \\
22 AB (G.oxydans) & $1.90 \pm 0.4$ & $4.2 \pm 0.3$ \\
123 D (A.pasteurianius) & $1.90 \pm 0.57$ & $13.9 \pm 0.2$ \\
44 AB (Gluconobacter.sp) & $1.85 \pm 0.1$ & $5.0 \pm 0.0$ \\
121 D (Acetobacter.sp) & $1.8 \pm 0$ & $38.1 \pm 0.3$ \\
05 D (Gluconobacter.sp) & $1.8 \pm 0.42$ & $12.9 \pm 0.3$ \\
08 AB (Gluconobacter.sp) & $1.75 \pm 0.1$ & $2.2 \pm 0.2$ \\
49 D (G.oxydans) & $1.75 \pm 0.21$ & $8.2 \pm 0.2$ \\
\hline
\end{tabular}

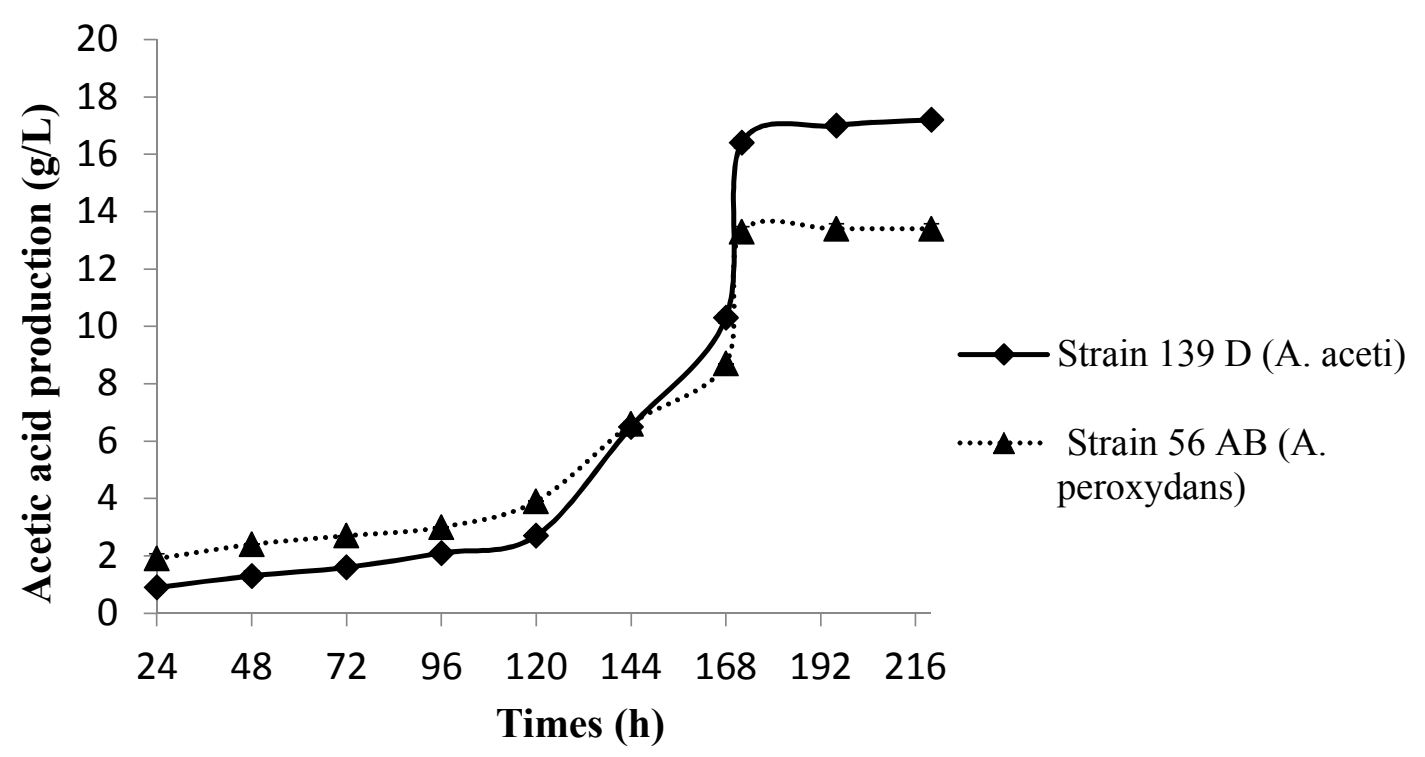

Figure 2. Time course of acid production during AAB growth.

+ Strains were cultured in HS liquid medium at $30{ }^{\circ} \mathrm{C}$ under aerobic atmosphere by stirring at $130 \mathrm{rpm}$ for 10 days. Acid yield was quantified in cell free supernatants by titration with $\mathrm{NaOH}(0.1 \mathrm{~N})$ and phenolphthalein as a color indicator.

The lag phase for acid production presented by our AAB strains is relatively long comparatively to that observed in many strains. For instance, $\mathrm{Lu}$ et al.[30]reported an acidproducing Acetobactersp strains from spoiled banana in Taiwan, with short lag phase $(12 \mathrm{~h})$. Furthermore, no lag phase for acid production was observed in Acetobacterpasteurianus strains isolated from palm wine[29] and traditional rice fermentation[22].The long lag phase observed in our AAB strains studied, may be indicative of their behavior in their natural ecosystem (cocoa fermentation) and seems to be a common property for $\mathrm{AAB}$ involved in cocoa fermentation since Romero-Cortes et al.[27]also reported a long lag phase (2 days) in AAB strain Acetobactertropicalis from Mexican cocoa fermentation. In fact, maximum production of acetic acid during cocoa fermentation occurs generally after the third day [7, 25] and AAB strains should keep a low level of acid production until this period which corresponds to the occurrence of reactions leading to formation of cocoa and chocolate aroma precursors.

On the other hand, the sharp rise in acid production observed after the fifth day of $\mathrm{AAB}$ culture indicate a possible existence, of biological signal that surely accelerate the catabolism from ethanol leading to high acid yield. For instance, $\mathrm{Lu}$ et al. [30] reported that maximum acetic acid production is achieved during the stationary growth phase.

\subsection{Biochemical Characterization of the Strains}

Acetic acid bacteria strains were identified as Gram 
negative, short rod-shaped, catalase positive, oxidase negative and obligatory aerobic. These bacteria formed colonies surrounded by characteristic yellow area on isolation medium. The 15 strains presenting highest acidifying capacity were subjected to further biochemical identification. Among these strains, 10 were able to further oxidise acetic acid and lactic acid into $\mathrm{CO}_{2}$ and $\mathrm{H}_{2} \mathrm{O}$ and subsequently classified as Acetobacter whereas 5 strains were not able to; these strains belong therefore to Gluconobactergenus. Three species including $A$. pasteurianus, $A$. aceti and $A$. peroxydans were identified among the strains highly producing acetic acid among the genera Acetobacter strains (Table 2).

All the Acetobacter strains presented the ability to grow at more than $10 \quad \%$ ethanol concentration. Acetobacterperoxydans was particularly characterized by acid production from glucose contrary to the others Acetobacter strains, while Acetobacteraceti was distinguished from Acetobacterpasteurianus from its capability to grow on mannose and to realize ketogenesis from glycerol. Additionally, unlike the other Acetobacter strains, Acetobacteraceti was not able to reduce nitrate into nitrite. However, the strain $121 \mathrm{D}$ yielding the most important acidity, belong toAcetobactergenus but was not further identified at species level by the biochemical methods used in this study. This strain 121D was therefore considered as Acetobacter sp. Likewise, among the five Gluconobacter strains only two isolates including $22 \mathrm{AB}$ and $49 \mathrm{D}$ were identified as $G$. oxydans the other strains were considered as Gluconobactersp(Table 2). The presence of Acetobacterpasteurianus and Acetobacteraceti among the best acid producers is consistent with previous studies reporting that, these species are generally known to be acid producer. Moreover, Acetobacterpasteurianus was assumed to be important for a successful cocoa bean fermentation process[31], probably due to its ability to produce acid as shown in this study. However, the results also show that the production of acetic acid in $\mathrm{AAB}$ strain from cocoa fermentation is not species-dependent since the yield of acid by strains belonging to the same species is extremely variable (Table 1).

Although the microflora characterized is limited, the results may be indicative of a certain diversity of $\mathrm{AAB}$ strains involved in Ivorian cocoa fermentation. These species were also found in Ghanaian, Brazilian and Mexican cocoa fermentation[11, 9,2].

Table 2. Biochemical properties of $A A B$ strains isolated.

\begin{tabular}{llllll}
\hline Isolates & Oxidation of lactic acid & Oxidation of acetic acid & Growth in $\mathbf{1 0} \%$ ethanol & Growth on manose & Growth on galactose \\
\hline $153 \mathrm{AG}$ & + & + & + & + & \\
$154 \mathrm{AG}$ & + & + & + & + & \\
$52 \mathrm{AB}$ & + & + & - & + & \\
$140 \mathrm{AG}$ & + & + & + & + & + \\
$56 \mathrm{AB}$ & + & + & - & + & \\
$139 \mathrm{AG}$ & + & + & + & + & \\
$168 \mathrm{AG}$ & + & + & + & + & \\
$121 \mathrm{D}$ & + & + & - & + & + \\
$123 \mathrm{D}$ & + & + & + & + & + \\
$139 \mathrm{D}$ & + & + & - & + & + \\
$49 \mathrm{D}$ & - & - & - & - & + \\
$08 \mathrm{AB}$ & - & - & - & + & + \\
$05 \mathrm{D}$ & - & - & - & + & + \\
$22 \mathrm{AB}$ & - & - & - & & + \\
$44 \mathrm{AB}$ & - & - & - & & + \\
\hline
\end{tabular}

Table 2. Continue.

\begin{tabular}{|c|c|c|c|c|c|}
\hline Isolates & Nitrate reduction & $\begin{array}{l}\text { Ketogenesis from } \\
\text { mannitol }\end{array}$ & Ketogenesis from glycerol & Acid production from D-glucose & AAB species \\
\hline $153 \mathrm{AG}$ & + & - & - & + & A.pasteurianius \\
\hline $154 \mathrm{AG}$ & - & + & + & + & A.aceti \\
\hline $52 \mathrm{AB}$ & - & + & + & + & A.aceti \\
\hline $140 \mathrm{AG}$ & + & - & - & + & A.pasteurianius \\
\hline $56 \mathrm{AB}$ & + & + & - & - & A.peroxydans \\
\hline $139 \mathrm{AG}$ & - & + & + & + & A.aceti \\
\hline $121 \mathrm{D}$ & + & ND & ND & + & \\
\hline $123 \mathrm{D}$ & + & - & - & + & A.pasteurianius \\
\hline $139 \mathrm{D}$ & - & + & + & + & A.aceti \\
\hline $49 \mathrm{D}$ & & + & + & & G. oxydans \\
\hline $08 \mathrm{AB}$ & & $N D$ & $N D$ & & Gluconobacter sp \\
\hline $05 \mathrm{D}$ & & $N D$ & $N D$ & & Gluconobacter sp \\
\hline $22 \mathrm{AB}$ & & + & + & & G. oxydanssp \\
\hline
\end{tabular}

ND : not deterninate, + : positive, -: negative 


\subsection{Survival of AAB Strains Under Stress Conditions}

\subsubsection{Alcohol Tolerance of AAB Strains}

To study the response of $\mathrm{AAB}$ strains to environmental stress conditions, 4 isolates presenting an important acidification capacity notably $123 \mathrm{D}$ (A. pasteurianus), $139 \mathrm{D}$ (A. aceti), $56 \mathrm{AB}$ (A. peroxydans) and $49 \mathrm{D}$ (G. oxydans) were selected as models. The results show that all the 4 strains are able to grow on medium containing up to $8 \%$ alcohol with a growth rate ranging from 11 to $66 \%$ (Figure $3 \mathrm{~A})$. However, two trends were observed concerning the ability of strains studied to grow under strong alcoholic conditions. First, Acetobacteraceti strain 139 D displayed the capacity to grow in alcohol at concentrations up to $12 \%$. At this concentration, the strains retained $45 \%$ of survival growth rate. However, beyond this concentration, a drastic decrease of survival capacity was observed. The second group including the strains 49 D (Gluconobacteroxydans), $123 \mathrm{D} \quad$ (Acetobacterpasteurianus), $56 \quad \mathrm{AB}$ (Acetobacetrperoxydans), and $121 \mathrm{D}$ (Acetobactersp) was characterized by a more sensitivity to alcoholic conditions. At $8 \%$ of alcohol, these strains kept less than $30 \%$ of
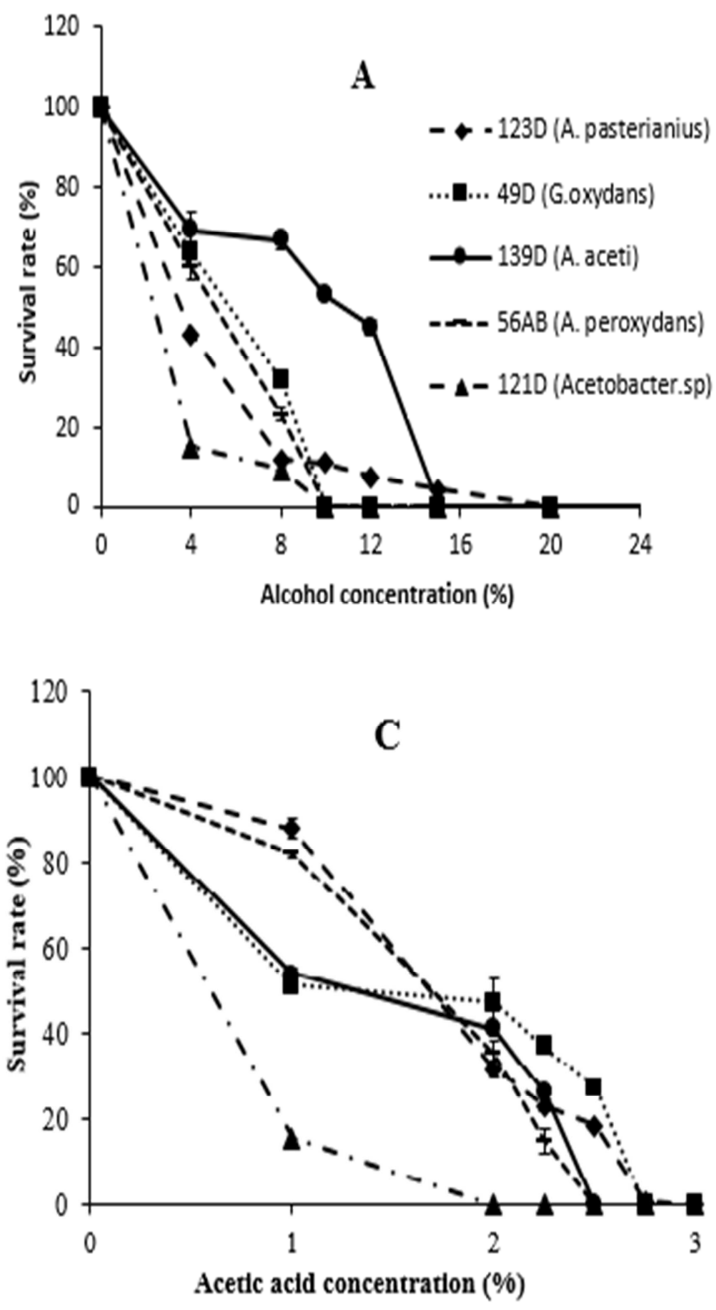

survival growth rate. Moreover, the best acid producer Acetobactersp strain $121 \mathrm{D}$ proved to be the less tolerant to alcohol. All the strains studied, failed to grow in medium containing more than $15 \%$ of alcohol.

Our results are in agreement with those of Vaughn,[32]indicating that the maximum alcohol concentration tolerated by acetic bacteria is between 14 and $15 \%$. These findings are also comparable to those of Sharafiet al.[28]who reported isolation of AAB strains from fruit with ability to grow at $11 \% \mathrm{v} / \mathrm{v}$ of ethanol. Previously, $\mathrm{Du}$ Toit and Pretorius,[33] observed that AAB remained viable in wine with $14 \%$ of ethanol.

Since alcohol concentration in the fermenting mass do not exceed $8 \%$, it is clear that the AAB strains isolated present an interesting behavior since they should be amply able to grow under alcoholic stress occurring in controlled cocoa fermentation. Ability to alcohol tolerance should be linked to their capacity to eliminate alcohol through oxidation into acetic acid. This propertie should be profitable since acetic acid formed is of great importance for quality of products.
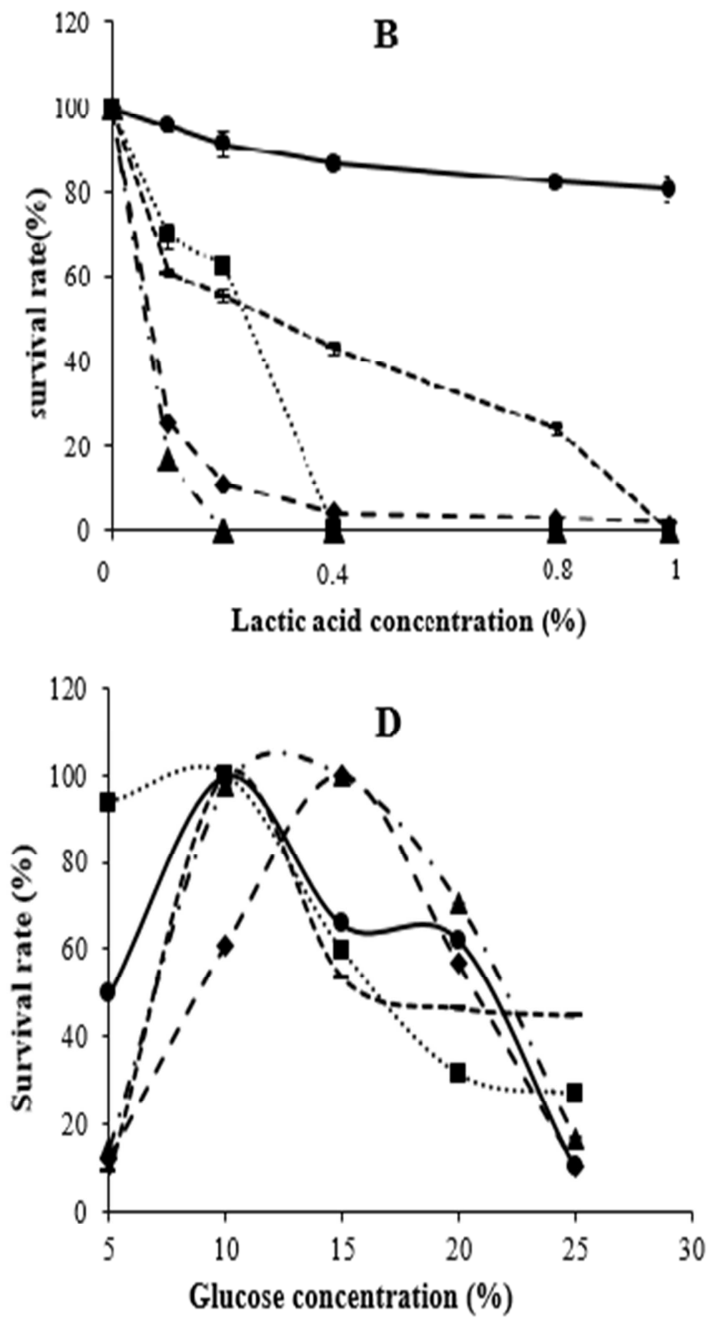

Figure 3. Effect of different compounds on AAB growth in vitro. 
+ Strains were grown on HS plate supplemented with corresponding volume of the compound to be tested and the plate was incubated at $30{ }^{\circ} \mathrm{C}$ for $72 \mathrm{~h}$. After incubation, microbial numeration was performed and the survival rate (\%) was calculated using $0 \%$ of compound as negative control except glucose for which the negative control was $15 \%$ corresponding to optimum bacterial growth. Error bars indicate standard deviations between three replicates.

\subsubsection{Response of AAB to Acid Stress}

Two groups of strains were observed concerning their ability to grow under acid condition induced by lactic acid. The first group including only Acetobacteraceti strain $139 \mathrm{D}$ was characterized by a strong tolerance to lactic acid, keeping more than $80 \%$ of survival growth rate under $1 \%$ lactic acid concentration (Figure 3B). This strain was able to conserve up to $30 \%$ of survival growth rate at $2 \%$ lactic acid (data not shown).

The second group was constituted by the strains $49 \mathrm{D}$ (Gluconobacteroxydans), 123 D (Acetobacterpasteurianus), $56 \mathrm{AB}$ (Acetobacterperoxydans), and $121 \mathrm{D}$ (Acetobactersp). These strains were characterized by a poor tolerance to lactic acid comparatively to the first group, failing to grow at $1 \%$. This is materialized by a sharp decrease of bacterial growth rate from 100 to $40 \%$ due to a small augmentation of lactic acid concentration from 0 to $0.4 \%$. The more acidifying Acetobacteraceti strain $121 \mathrm{D}$ proved to be the most sensitive to lactic acid among the strains analyzed (Figure 3B).

The same grouping was observed when bacterial strains are grown in citric acid (data not shown). However, the strains analyzed revealed to be more tolerant to acetic acid than the other acids. Figure $3 \mathrm{C}$ shows that all the strains grow at more than $2 \%$ of acetic acid apart from the Acetobactersp strain $121 \mathrm{D}$, the most acidifying strain. While the Acetobactersp strain $121 \mathrm{D}$ failed to grow at $2 \%$ of acetic acid, the other strains have a survival rate comprised between 14 and $47 \%$. No bacterial growth was observed at $3 \%$ acetic acid.

Since, acidity from acetic acid in cocoa fermentation, is very important for obtaining a high quality of chocolate $[2,14]$, it could be assumed that fermentation containing high acid-producing $\mathrm{AAB}$ strains such as $121 \mathrm{D}$, is more liable to generate high precursors content due to acidic activation of complexes enzymes into beans namely aspartic endoprotease and serine carboxypetidase. To this point of view, the screening of microbial strains with particular performance is of great importance. However, a starter should also be able to survive under environmental stress. Hence, although the strains $121 \mathrm{D}$ yielded the most important amount of acid, this strain should not be a valuable starter due to its poor resistance to acid stress.

Moreover, lactic acid proved to have the most hindering effect among the acids tested on AAB growth. The general mechanism of adaptation to environmental stress is very complex and involve a sigma factor protein that is aided by alarmones of stringent response namely hyperphosphorylated guanosine nucleotides[34]. The effectiveness of a bacterial response is therefore determined by the functioning of this system.

\subsubsection{Effects of Temperature and pH on AAB Growth}

Table 3 shows that AAB strains $123 \mathrm{D}$ and $49 \mathrm{D}$ present maximal growth at $35^{\circ} \mathrm{C}$ displaying a turbidity $\mathrm{OD}_{600}$ of 2.34 and 1.23 , respectively, although the growth was already at high level at $30{ }^{\circ} \mathrm{C}\left(\mathrm{OD}_{600}=2.72\right)$. In contrast, the strains $139 \mathrm{D}$ and $56 \mathrm{AB}$ presented maximal growth at $30{ }^{\circ} \mathrm{C}\left(\mathrm{OD}_{600}\right.$ $=1.65$ and 1.99 respectively), but recorded a strong decrease of bacterial growth at $35{ }^{\circ} \mathrm{C}\left(\mathrm{OD}_{600}=0.53\right.$ and 0.44 respectively). Furthermore, it was observed that most of strains analyzed present a growth at 45 and $50{ }^{\circ} \mathrm{C}$ as indicated by the turbidity comparatively to the negative control. However, the growth at these temperatures (45 and $50{ }^{\circ} \mathrm{C}$ ) remained 2 to 20 -folds lower than that observed at optimal temperatures. The lower survival rate for the temperatures beyond $40{ }^{\circ} \mathrm{C}$ suggests that our $\mathrm{AAB}$ strains may not be fully viable at these temperatures in fermentation conditions. In fact, the growth of acetic acid bacteria is associated with an exothermic process in the fermentation heaps which raises the temperature of fermenting beans up to $40{ }^{\circ} \mathrm{C}$ at $72 \mathrm{~h}$ [8]. The elevation of the temperature could be linked to the production of acid by AAB. Lu et al.[35] also found that thermotolerantAcetobacter strain produced more acetic acid (up to $41 \mathrm{~g} / \mathrm{L}$ ) in comparison with two non thermotolerant strains. So beyond $40{ }^{\circ} \mathrm{C}$, a low population level may be responsible for a high specific production of acid.

Table 3. Effect oftemperature on AAB growth in vitro.

\begin{tabular}{lllllll}
\hline Strains & species & $\mathbf{3 0}^{\mathbf{0}}$ & $\mathbf{3 5}^{\mathbf{}} \mathbf{c}$ & $\mathbf{4 0}^{\mathbf{}} \mathbf{c}$ & $\mathbf{4 5}^{\mathbf{0}} \mathbf{c}$ & $\mathbf{5 0} \mathbf{c}$ \\
\hline $123 \mathrm{D}$ & A. pasteurianus & $2.172 \pm 0.15$ & $2.544 \pm 0.056$ & $1.074 \pm 0.074$ & $0.00 \pm 0.00$ & $0.00 \pm 0.00$ \\
$49 \mathrm{D}$ & G. oxydans & $1.259 \pm 0.011$ & $1.328 \pm 0.092$ & $0.791 \pm 0.038$ & $0.691 \pm 0.109$ & $0.428 \pm 0.013$ \\
$139 \mathrm{D}$ & A. aceti & $1.655 \pm 0.036$ & $0.537 \pm 0.063$ & $0.405 \pm 0.003$ & $0.358 \pm 0.003$ & $0.114 \pm 0.006$ \\
$56 \mathrm{AB}$ & A. peroxydans & $1.992 \pm 0.013$ & $0.445 \pm 0.002$ & $0.377 \pm 0.070$ & $0.187 \pm 0.014$ & $0.132 \pm 0.009$ \\
\hline
\end{tabular}

+ The AAB strains were grown in YEPG broth and then the cultures were incubated at different temperatures during $72 \mathrm{~h}$. The absorbance $\left(\mathrm{OD}_{600}\right)$ was measured at $6 \mathrm{~h}$ intervals to monitor the microbial growth during incubation.
Concerning the effect of $\mathrm{pH}$, maximum growth was observed at $\mathrm{pH} 5$ for all the strains analyzed except the strain $123 \mathrm{D}$ which presented a higher growth rate at alkaline $\mathrm{pH}$ (8). Nearly, no growth was observed at $\mathrm{pH} 3$ and below. 
However, strains presenting maximum growth at acidic $\mathrm{pH}$ still have a relatively high growth at alkaline $\mathrm{pH}$. Hence acidic $\mathrm{pH}$ have more severe effect on bacterial growth than basic $\mathrm{pH}$ (Table 4).

The growth of isolates at different $\mathrm{pH}$ is confirmed by $\mathrm{Du}$ Toit and Pretorius,[33]who observed an increase of AAB growth in wine, vinegar and beer at $\mathrm{pH}$ ranging from 2 to 6.5 . It was also indicated that optimum $\mathrm{pH}$ for $\mathrm{AAB}$ growth is between 5.4 and 6.3[36]. However, the maximum growth rate occurring at $\mathrm{pH} 8$, observed in $A$. pasteurianus isolated, constitute a particular trait. This could be explained by adaptation of this strain to cocoa fermentation conditions. Indeed, many studies reported the particular increase of $\mathrm{pH}$ to 7.9-8 at the end of spontaneous cocoa fermentation in Côte d'Ivoire[37,19,38].

Table 4. Effect of $p H$ on $A A B$ growth in vitro.

\begin{tabular}{llllllll}
\hline Strains & species & $\mathbf{p H ~ 2}$ & $\mathbf{p H ~ 3}$ & $\mathbf{p H ~ 5}$ & $\mathbf{p H ~ 7}$ & $\mathbf{p H ~ 8}$ \\
\hline $123 \mathrm{D}$ & A. pasteurianus & $0.050 \pm 0.001$ & $0.050 \pm 0.006$ & $1.964 \pm 0.117$ & $2.176 \pm 0.005$ & $2.562 \pm 0.014$ \\
$49 \mathrm{D}$ & G. oxydans & $0.076 \pm 0.032$ & $0.149 \pm 0.121$ & $2.196 \pm 0.008$ & $1.915 \pm 0.018$ & $0.744 \pm 0.007$ \\
$139 \mathrm{D}$ & A. aceti & $0.047 \pm 0.007$ & $0.129 \pm 0.029$ & $0.333 \pm 0.004$ & $0.265 \pm 0.005$ & $0.129 \pm 0.008$ \\
$56 \mathrm{AB}$ & A. peroxydans & $0.036 \pm 0.004$ & $0.066 \pm 0.005$ & $0.815 \pm 0.006$ & $0.874 \pm 0.004$ & $0.447 \pm 0.024$ \\
\hline
\end{tabular}

+ The AAB strains were grown YEPG broth adjusted to different $\mathrm{pH}$ was incubated at $30{ }^{\circ} \mathrm{C}$ for $72 \mathrm{~h}$. The absorbance $\left(\mathrm{OD}_{600}\right)$ was measured at $6 \mathrm{~h}$ intervals to monitor the microbial growth during incubation.

\subsubsection{Effect of Osmotic Stress Induced by Glucose on AAB Growth}

Maximum growth was obtained at $10 \%$ of glucose concentration for all the strains excepted the strain $123 \mathrm{D}$ Acetobacterpasteurianus. However, the growth is still relatively high at sugar concentrations in the range 10 to $15 \%$, with relative growth between 60 and $100 \%$ (Figure 3D). Moreover, above $25 \%$ of glucose concentration, bacterial growth is severely affected.

\section{Conclusion}

In this study, acetic acid bacteria presenting high acidification capacity involved in Ivorian cocoa fermentation have been characterized and their ability to grow under fermentative stress conditions have been evaluated. Acetic acid bacteria isolated from Ivorian cocoa fermentation present different levels of acid production, some yielding more acid than others. Different species namely Acetobacteraceti,A. peroxydans, A. Pasteurianus and Gluconobacteroxydans were found to be acid producers. The acidifying AAB strains behaved differently under different stress conditions. Lactic acid was found to have the most hindering effect on the growth of AAB.This study outline a certain diversity of AAB involved in Ivoirian cocoa fermentation and shows the relevance to screen among them the most valuable strain as potential starter for improvement of cocoa fermentation.

\section{Acknowledgment}

This research was supported by the International Foundation for Science (IFS), Sweden, under grant E/4411-2.

\section{References}

[1] Biehl, B., Voigt, J., Heinrichs, H., Senjuk, V. and Bytof, G. (1993).pH-dependent enzymatic formation of oligopeptides and amino acids, the aroma precursors in raw cocoa beans. In: Lafforest, J. (Ed.), Proceedings in XIth International Cocoa Research Conference. Cocoa Producers' Alliance, Yamassoukro, Ivory Coast, pp. 717-722.

[2] Schwan, R.F. and wheals, A.E. (2004). The microbiology of cocoa fermentation and its role in chocolate quality. Crit. Rev. Food Sci. Nutr. 44:204-221.

[3] Lima,L.J.R., Almeida,M.H., Nout, M.J.R., Zwietering,M.H.(2011). TheobromacacaoL., "the food of the gods": quality determinants of commercial cocoa beans, with particular reference to the impact of the fermentation. Crit. Rev. Food Sci. 52:731-761.

[4] De Brito, E.S., Pezoa-Garcia, N.H., Gallao, M.I., Cortelazzo, A.L., Fevereiro, P.S. and Braga, M.R. (2000).Structural and chemical changes in cocoa (Theobroma cacao L) during fermentation, drying and roasting.J. Sci. Food Agric. 81: 281288 .

[5] Lefeber, T., Papalexandratou, Z., Gobert, W., Camu, N. and De Vuyst, L. (2012). On-farm implementation of starter culture for improved cocoa bean fermentation and its influence on the flavor of chocolate produced thereof. Food Microbiol. 30:379-392.

[6] Crafack, M., Mikkelsen, M., Saerens,S., Kundsen, M.,Blenbow, A., Lowor,S.,Takrama, J., Swiegers,J., Petersen,G.B.,Heimdal, H. and Nielsen, D. S. (2013). Influencing cocoa flavor using Pichiaklutveri and Kluyveromycesmarxianus in a defined starter culture for cocoa fermentation. Int. J. Food Microbiol. 167:103-116.

[7] Schwan, R. F. (1998). Cocoa fermentation conducted with a defined microbial cocktail inoculum. Appl. Env. Microbiol. 64:1477-1483.

[8] Ardhana, M. and Fleet,G. (2003). The microbial ecology of cocoa bean fermentations in Indonesia.Int. J. Food Microbiol. 86:87-99. 
[9] Nielsen, D.S., Teniola, O.D., Ban-Koffi, L., Owusu, M., Andersson, T., Holzapfel, W.H., (2007). The microbiology of Ghanaian cocoa fermentations analysed using culture dependent and culture independent methods. Int. J. Food Microbiol. 114: 168-186.

[10] Ouattara, H.G., Ban-Koffi, L., Karou, G.T., Sangare, A., Niamke, S.L. and Diopoh, J.K., (2008). Implication of Bacillus sp. in the production of pectinolytic enzymes during cocoa fermentation.World J. Microbiol. Biotechnol. 24: 17531760.

[11] Papalexandratou, Z., Vranckena, G., De Bruyne, K., Vandamme, P. and De Vuyst, L. (2011). Spontaneous organic cocoa bean box fermentations in Brazil are characterized by a restricted species diversity of lactic acid bacteria and acetic acid bacteria. Food Microbiol. 28:1326-1338.

[12] Hansen, C.E., delOlmo M., and Burri, C. (1998). Enzyme activities in cocoa beans during fermentation.J. Sci. Food Agric. 77:273-281

[13] Nielsen, D.S., Hønholt, S., Tano-Debrah, K., Jespersen, L. (2005). Yeast populations associated with Ghanaian cocoa fermentations analysed using denaturing gradient gel electrophoresis (DGGE). Yeast. 22: 271-284.

[14] Lefeber, T., Janssens, M., Camu, N., De Vuyst, L. (2010). Kinetic analysis of strains of lactic acid bacteria and acetic acid bacteria in cocoa pulp simulation media to compose a starter culture for cocoa bean fermentation.Appl. Env. Microbiol.76: 7708-7716.

[15] Amin, I., Jinap, S. and Jamilah, B. (1998).Proteolytic activity (aspartic endoproteinase and carboxypeptidase) of cocoa bean during fermentation.J. Sci. Food Agric. 76: 123-128.

[16] Forsyth, W. G. C. and Quesnel, V. C. 1963. Mechanisms of cocoa curing. Adv. Enzymol. 25:457-492.

[17] De Vuyst, L., Lefeber, T., Papalexandratou, Z., Camu, N. (2010). The functional role of lactic acid bacteria in cocoa bean fermentation. In: Mozzi, F., Raya, R.R.,Vignolo, G.M. (Eds.), Biotechnology of Lactic Acid Bacteria: Novel Applications. Wiley-Blackwell, Ames, pp. 301e326.

[18] Lefeber, T., Gobert, W., Vrancken, G., Camu, N., De Vuyst, L. (2011). Dynamics and species diversity of communities of lactic acid bacteria and acetic acid bacteria during spontaneous cocoa bean fermentation in vessels.FoodMicrobiol. 28: 457-464.

[19] Yao, W., Ouattara,H.G. Goualie, B., Soumahoro, S. and Niamke,S. (2014). Analysis of some functional properties of acetic acid bacteria involved in Ivorian cocoa fermentation. J. Appl. Biosci. 75:6282-6290.

[20] Duthathai, F. and Pathom-Aree, W. (2007). Application of chemical dyes as colour indicator for selective isolation of acetic acid bacteria.Res. J. Microbiol. 2: 885-888.

[21] Andelib, A.Y. and Nuran, D.A. (2009). Isolation of cellulose producing bacteria from wastes of vinegar fermentation. In: Proceedings of the World Congress on Engineering and Computer Science Vol I, San Francisco, USA. pp. 978-988.

[22] Nanda K., Taniguchi M., Ujike S., Ishihara N., Mori H., Ono H.andMurooka Y. (2001). Characterization of acetic acid bacteria in traditional acetic acid fermentation of rice vinegar (komesu) and unpolished rice vinegar (kurosu) produced in Japan. Appl. Env. Microbiol. 67. 986-990.
[23] Buchanan, R.E. and Gibbons, N.E. (1974). Bergey's s Manual of Determinative Bacteriology (8th ed.). The Williams and Wilkins Co., Baltimore.

[24] Carr,J.G.(1968). Identification of acetic acid bacteria. In Identification methods for Microbiologists, Part B. Gibbs BM, Shapton DA (eds). Academic Press, London, pp 1-8.

[25] Pereira, G.V.M., Migue, M.G.C.P.,Ramos,C.L.,SchwanR.F.(2012). Microbiological and Physicochemical characterization of small scale cocoa fermentations and screening of yeast and bacterial strains to develop a defined starter culture. Appl. Env. Microbiol.78:5395-5405.

[26] Samagaci L., Ouattara, H.G., Goualié, B.G. and Niamke, S. L. (2014). Growth capacity of yeasts potential starter strains under cocoa fermentation stress conditions in Ivory Coast. Emir. J. Food Agric.26 (10) : 861-870.

[27] Romero-Cortes, T., Robles-Olvera, V., Rodriguez-Jimenes, G. and Ramírez-Lepe, M. (2012). Isolation and characterization of acetic acid bacteria in cocoa fermentation. Afr. J. Microbiol. Res. 6. (2). 339-347.

[28] Sharafi,S.M., Rasooli, I., Beheshti-Maal, K. (2010). Isolation, characterization and optimization of indigenous aceticacid bacteria and evaluation of their preservation methods.Iran. J. Microbiol. 2 (1): 41-48.

[29] Konate, M., Akpa, E.E., Koffi,L.B.,Kra,K.A.S.,Megnanou RM. andNiamkeS.(2014). Isolation of thermotolerant and high acetic acid-producing Acetobacterpasteurianusfrom Ivorian palm wine.Emir. J. Food Agric. 26 (9): 773-785.

[30] Lu, S-F., Lee, F-L. and Chen, H.-K. (1998). A thermotolerant and high acetic acid-producing bacterium Acetobacter sp. I14-2.J. Appl. Microbiol. 86. 55-62.

[31] Papalexandratou, Z., T.B. Lefeber, , B. Bahrim, O.S. Lee, HM. Daniel and L. De Vuyst.(2013). Hanseniasporaopuntiae, Saccharomyces cerevisiae, Lactobacillus fermentum, and Acetobacterpasteurianus predominate during well-performed Malaysian cocoa bean box fermentations, underlining the importance of these microbial species for a successful cocoa bean fermentation process. Food Microbiol.35 : 73 - 85 .

[32] Vaughn, R.H.,Camargo, R.,Falanghe, H.,Mello-Ayres, G.,Serzedello, A.(1958). Observations on the microbiology of the coffee fermentation in Brazil.Food Technol. 12, 357-360.

[33] Du Toit, W. J. and Pretorius, I. S. (2002). The occurrence, control and esoteric effect of acetic acid bacteria in winemaking.Annals of Microbiology. 52. 155-179.

[34] Cashel, M., Gentry, D.R., Hernandez, V.J., and Vinella, D.(1996). The stringent response, p. 1458-1496.In F. C. Neidhardt, R. C. Curtiss III, J. L. Ingraham, E. C. C. Lin, K. B. Low, B. Magasanik, W. S. Reznikoff, M. Riley, M. Schaechter, and A. E. Umbarger (ed.), Escherichia coli and Salmonella: cellular and molecular biology, 2nd ed., vol. 1.ASM Press, Washington, DC.

[35] Lu S-F., Lee F-L.and Chen H-K. (1999). A thermotolerant and high acetic acid-producing bacterium Acetobacter sp.I14-2.J. Appl. Microbiol. 86. 55-62.

[36] Holt, J.G., Krieg,N.R., Sneath, P.H.A. and Staley, J.T. (1994). Bergey's Manual of Determinative Bacteriology. Williams \& Wilkins, Baltimore, Maryland. 
[37] OuattaraD.H., OuattaraH.G.,GoualiéB.G., KouameL.M., NiamkeS.L,(2014). Biochemical and functional properties of lactic acid bacteria isolated from Ivorian cocoa fermenting beans. J. Appl. Biosci. 77:6489- 6499 (2014).
[38] Guehi, S.T., Dabone,S., Ban-Koffi,L.,Kra, D.K. and Zahouli, G.I. (2010). Effect of turning beans and fermentation method on the acidity and physical quality of raw cocoa beans. Adv. J. Food Sci. Technol. 2:163-171. 